\title{
Discovery of an earliest Triassic, post-extinction foraminiferal assemblage above the Permian-Triassic boundary, Strandzha nappes, north-west Turkey
}

\author{
Cengiz OKUYUCU ${ }^{1, *}$, Daria IVANOVA ${ }^{2}$, Yavuz BEDI ${ }^{3}$ and Ali ERGEN ${ }^{3}$ \\ 1 Selçuk University, Faculty of Engineering, Department of Geological Engineering, Alaeddin Keykubat Kampüsü, Selçuklu, \\ Konya, Turkey \\ 2 Bulgarian Academy of Science, Institute of Geology, Acad. G. Bonchev bl. 24, 1113, Sofia, Bulgaria \\ 3 General Directorate of Mineral Research and Exploration (MTA), Department of Geological Research, Üniversiteler \\ Mahallesi Dumlupınar Bulvarı No: 139, Çankaya, Ankara, Turkey
}

Okuyucu C., Ivanova D., Bedi Y. and Ergen A. (2014) Discovery of an earliest Triassic, post-extinction foraminiferal assemblage above the Permian-Triassic boundary, Strandzha nappes, north-west Turkey. Geological Quarterly, 58 (1): 117-124, doi: $10.7306 / g q .1145$

A new foraminiferal fauna from Early Triassic (Induan) strata of the Çağlayık section on the "Strandzha Massif", north-west Turkey, comprises five species precisely determined and five species in open nomenclature belonging to ten genera. They belong to the post-extinction foraminiferal assemblage of the Permian-Triassic crisis, characterized by the presence of both disaster taxa (Earlandia and Postcladella kalhori) and Lazarus taxa (Diplosphaerina inaequalis, ?Rectostipulina quadrata, Arenovidalina sp. and Glomospira sp.). The present study at Tütünlüktepe Formation identified for the first time the Permian foraminifers on the Strandzha Massif as relict members of a post-extinction foraminiferal assemblage.

Key words: Permian-Triassic boundary, post extinction, foraminifera, Strandzha, Turkey.

\section{INTRODUCTION}

The "Strandzha Massif" or the Istranca Composite Terrane (Hagdorn and Göncüoğlu, 2007) is one of the complex tectonic units or terranes in Bulgaria and Turkey that covers almost $1200 \mathrm{~km}^{2}$ across the Turkish-Bulgarian border. The structural properties and geological settings of the Strandzha Terrane have been recently reviewed in some detail by Bulgarian (Gerdjikov, 2005a, b; Dabovski and Zagorchev, 2009) and Turkish (Okay et al., 2001) researchers. The first geological study on the Turkish part of the "Strandzha Massif" was carried out by Pamir and Baykal (1947). Later, some general geological studies were realized in the "massif" by Üşümezsoy (1982) and Aydın $(1974,1982)$. According to the recent classification of Okay and Yurtsever (2006) the "Strandzha Massif" which extends along the Black Sea coast is comprised of two main geological units, being metamorphic rocks of the "Strandzha Massif" and the Thrace Basin. The crystalline rocks of the "Strandzha Massif" have been classified in three main groups by previous researchers: a) low and high grade basal metamorphic rocks, b) plutonic rocks that belong to the basement and c)

\footnotetext{
*Corresponding author, e-mail: okuyucucengiz@gmail.com
}

Received: August 6, 2013; accepted: November 4, 2013; first published online: January 15, 2014
Triassic and Jurassic meta-sedimentary rocks which form the cover succession. Recent studies, carried out both in the Bulgarian and Turkish parts of the "Strandzha Massif", have shown the presence of nappe structures in the "massif" (Şengör et al., 1984; Okay et al., 2001; Gerdjikov, 2005a, b). Recently, Bedi et al. (2013) recognized different nappe structures in the Turkish part of the "Strandzha Massif".

We discovered Early Triassic foraminifera in recrystallised limestones to the south-east of Çağlayık village (Fig. 1) and found the evidence for a post-extinction foraminiferal assemblage above the Permian-Triassic boundary.

The Permian-Triassic mass extinction event was the most severe of the Phanerozoic mass extinctions (Erwin, 1993) with more than $90 \%$ of marine species eliminated because of the destruction of the marine ecosystem (Jin et al., 2000; Bambach et al., 2002). Potential causes and effects of the end-Permian mass extinction have been proposed remain in debate. Triggers such as a bolide impact, volcanic eruptions, oceanic anoxia, rapid climate change, catastrophic release of seafloor methane and so on (Baud et al., 1989; Erwin, 1993, 2006; Wignall and Twitchett, 1996; Hallam and Wignall, 1999; Becker et al., 2001; Kaiho et al., 2001; Weidlich et al., 2003; Knoll et al., 2007) have been suggested as the most likely causes for this crisis.

The foraminifers are one of the most important fossil groups through the P-Tr transition because they are very common and distributed in a variety of facies settings. They enable understanding of biotic extinction pattern via quantitative analysis and their evolutionary history across the P-Tr transition (Rampino and Adler, 1998; Jin et al., 2000; Groves et al., 2005; Song et al., 2009a, b, 2013) 


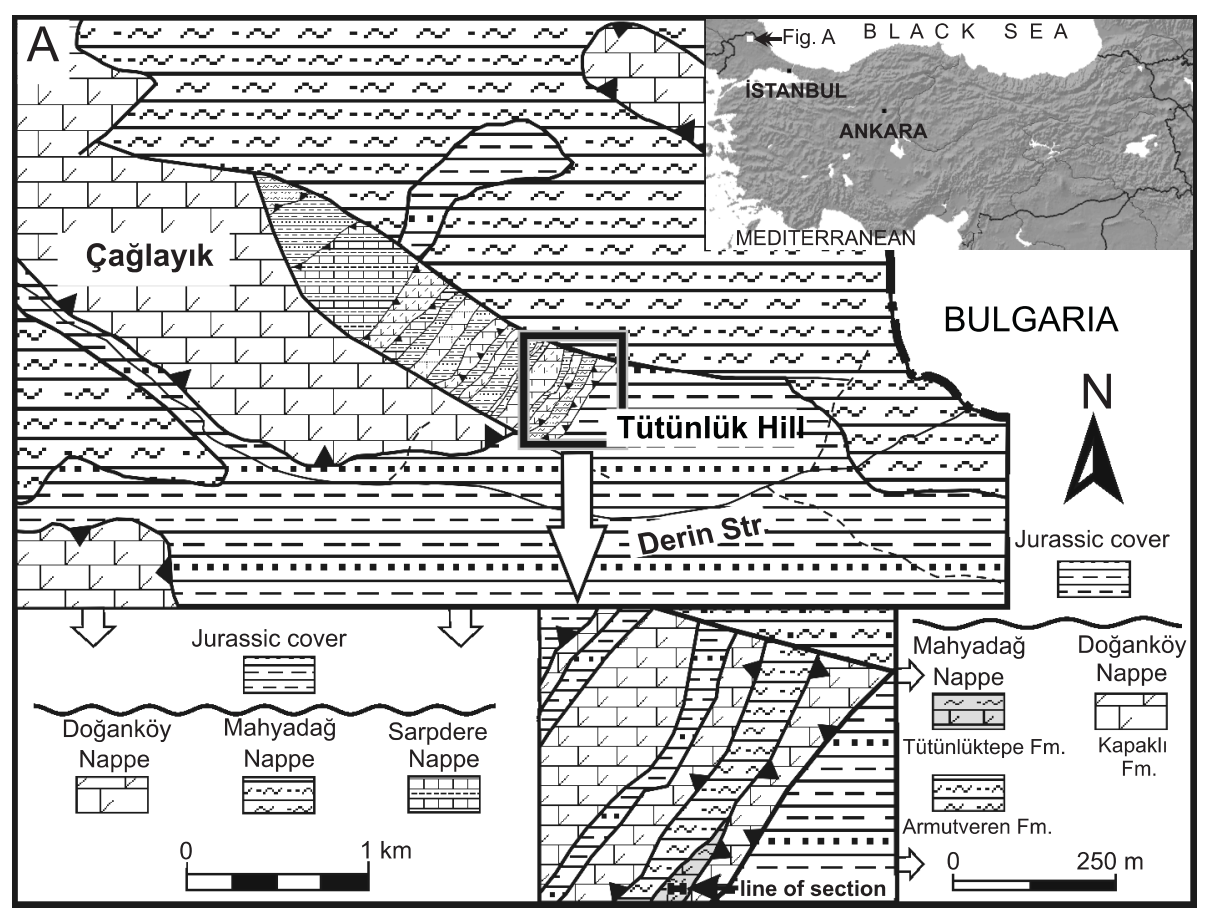

Fig. 1. Geographical and the geological map of the study area and location of the Çağlayık section (after Bedi, 2009)

A section of recrystallised limestones is well-exposed in the Turkish part of the "Strandzha Massif" and up until now has not been found in Bulgaria where Early Triassic foraminifera-bearing recrystallised limestones have only been documented by Trifonova (1978, 1984, 1992, 1993, 1994), Chatalov and Trifonova (1985) and Chatalov (1990) from the Peri-Tethyan (Subbalkanide) type (Sveti Ilija Ridge) and Tethyan (Strandzha) type Triassic of Strandzha Mountain (south-east Bulgaria). In the limestones belonging to the Omarcevo Formation (Sveti llija Ridge), the Lower Triassic Meandrospira pusilla acme-zone with a characteristic of the Spathian Stage foraminiferal association has been recognized. The species Meandrospira pusilla (Brönnimann), Arenovidalina chialingchiangensis (Ho), Cyclogyra mahajeri Broennimann, Zaninetti and Bozorgnia, Kamurana chatalovi Trifonova, Ammodiscus multivolutus (Reitlinger), and Glomospira sinensis Ho have been determined and figured. In the Tethyan (Strandzha) type Triassic the Lower Triassic corresponds to the lower and middle part of the Goljamo Bukovo Formation (Chatalov and Trifonova, 1985) where only few foraminifera species have been found, such as Meandrospira pusilla (Ho), Nodosinella cf. rostrata Trifonova, Ammodiscus sp., and Nodosaria sp. The aim of this study is to document the Early Triassic foraminifers (Induan) and to show the first post-extinction foraminiferal assemblage above the P-Tr transition in the Strandzha Nappes, north-west Turkey. Thus, the newly found foraminifers provide some insights into Early Triassic biostratigraphy and the foraminiferal extinction pattern across the P-Tr transition.

\section{GEOLOGICAL SETTING}

Recent studies along the Turkish-Bulgarian border have shown the presence of tectonic units which completely differ in stratigraphy, lithology and metamorphic features, and have revealed their thrust contacts between them (Bedi et al., 2013). These structural units in Turkey are called the Sarpdere Nappe (Subbalkanide type Triassic of Chatalov, 1980), the Mahyadağ Nappe (Strandzha type Triassic of Chatalov, 1980) and the Doğanköy Nappe (Sakar type Triassic of Chatalov, 1980 ) in ascending order. These three nappes are sealed by Lower Jurassic siliciclastic deposits.

The Early Triassic foraminifera in the recrystallised limestones were discovered in the Tütünlüktepe Formation of the Mahyadağ Nappe (Fig. 2) which is composed of Devonian (?)-Triassic successions. The lowermost Paleozoic succession of the Mahyadağ Nappe is Devonian (?)-Permian in age and is called the Armutveren Formation. The Armutveren Formation is composed of intercalations of reddish, yellowish, thin-bedded quartzite and calc-schist, dolomite and recrystallised limestone. The Tütünlüktepe Formation, which is 10-m-thick, displays discontinuous outcrops in the Turkish part of the "Strandzha Massif" and comprises intercalations of grey, dark grey, thin- to medium - and regularly-bedded recrystallised limestone and green, thinly foliated metasiltstone. This unit is observed around Tütünlüktepe Hill only on the road between Dereköy-Çağlayık in the Turkish portion of the "Strandzha Massif". The Tütünlüktepe Formation is underlain conformably by the Devonian (?)-Permian Armutveren Formation (Figs. 2 and 3). The Tütünlüktepe and the Armutveren formations are overlain with angular unconformity by the Early Triassic Çukurpınar Formation which is equivalent the the Struvnitsa Formation of Chatalov (1985) in Bulgaria and composed of metasiltstone, metaconglomerate with quartz schist interbeds, metamicroconglomerate and coarse-grained metasandstone. The Middle-Upper Triassic Adatepe, Tolpan, Kalina Chuka, Kaynakdere and Karlık formations are the succeeding units of Mahyadağ Nappe (Fig. 2). 


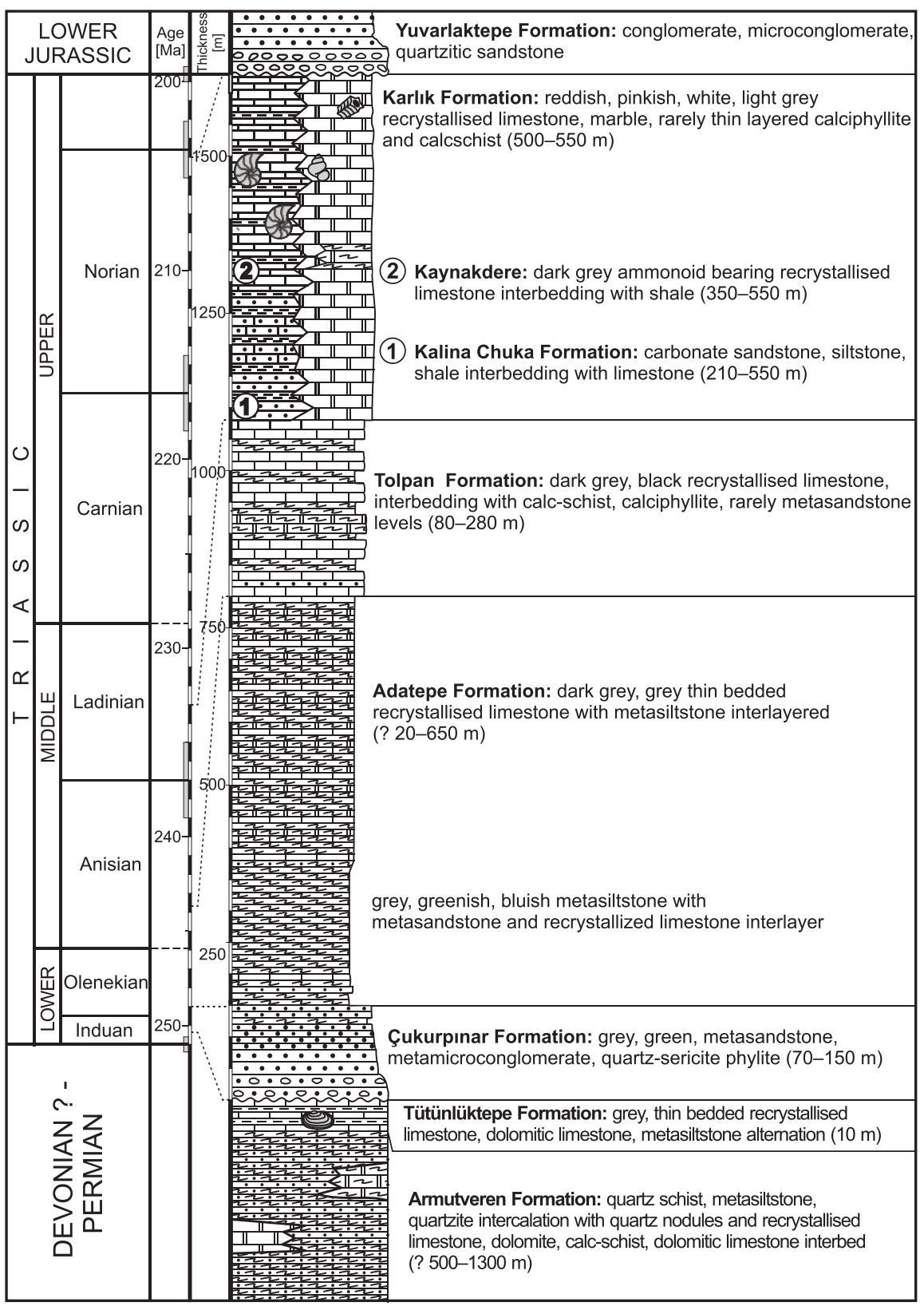

Fig. 2. Generalized stratigraphic columns of the Mahyadağ Nappe (Bedi et al., 2013)

\section{MATERIAL}

Twenty-five samples from the Çağlayık section (Kırklareli, south-east of Çağlayık village) were collected from the recrystallised limestones, dolomitic limestones and metasiltstones exposed there (Fig. 4). Dolomitic and recrystallised limestones levels are relatively rich in foraminiferal assemblages and represented by well-preserved specimens (Figs. 5 and 6). The collected samples have been processed for conodonts, but proved barren. Thin sections of the studied material are deposited in the MTA (General Directorate of Mineral Research and Exploration of Turkey) Paleontology Division.

\section{RESULTS}

Based on the relatively rich and well-preserved foraminiferal fauna, the rocks from the Çağlayık section have been effectively distinguished and classified (Figs. 5 and 6). The first sample (09-KK-214) from the base of the section was barren as regards foraminifera. The sample (09-KK-215) from the overlying bed contains very rare foraminifera represented by only Ammodiscus sp. and Arenovidalina chialingchiangensis (Ho). Sample 09-KK-216 is rich in foraminifera, including Hemigordius sp., Ammodiscus sp., Arenovidalina chialingchiangensis ( $\mathrm{Ho})$, Globivalvulina bulloides (Brady), Glomospira sp., ?Rectostipulina quadrata Jenny-Deshusses, Diplosphaerina inaequalis (Derville), Earlandia sp. and Postcladella kalhori (Brönnimann, Zaninetti and Bozorgnia). This part of the section is characterized by the presence of two Lazarus taxa, Diplosphaerina inaequalis (Derville) and ?Rectostipulina quadrata Jenny-Deshusses and two disaster species Postcladella kalhori (Brönnimann, Zaninetti and Bozorgnia) and Earlandia sp. This association characterizes the post-extinction foraminiferal assemblage after the Permian-Triassic mass extinction and is also present in the upper part of the section. The palaeobiogeographic distribution of these short-lived disaster forms is known from the western Tethyan area including Italy, Hungary, Yugoslavia, Bulgaria, Austria, Turkey and Iran (Trifonova, 1978; Rettori, 1995; Ünal et al., 2003; Groves and Altıner, 2005). Foraminifers recovered from samples 09-KK-218 and 09-KK-219 are very rare and they are assigned to only one species, Ammodiscus sp. Sample 09-KK-220 includes similar specimens to those described from 09-KK-216, with Ammodiscus sp., Hemigordius sp., Earlandia sp., Arenovidalina chialingchiangensis (Ho), Postcladella kalhori (Brönnimann, Zaninetti and Bozorgnia), Glomospira sp. After four barren samples ?Rectostipulina quadrata JennyDeshusses was found in sample 09-KK-225. The upper parts of the Çağlayık section yielded foraminifers, apart from sample 09-KK-226. The foraminiferal assemblages of sample 09-KK227, 09-KK-228 and 09-KK-229 are Ammodiscus sp., Hemigordius sp., Diplosphaerina inaequalis (Derville) and Endoteba? sp. respectively. The foraminiferal abundance of the last samples from the recrystallised limestone level of the section is much smaller than in the underlying beds. Sample 10-KK-228 is the only sample that shows strongly recrystallised Lower Triassic ooids within all studied samples. 


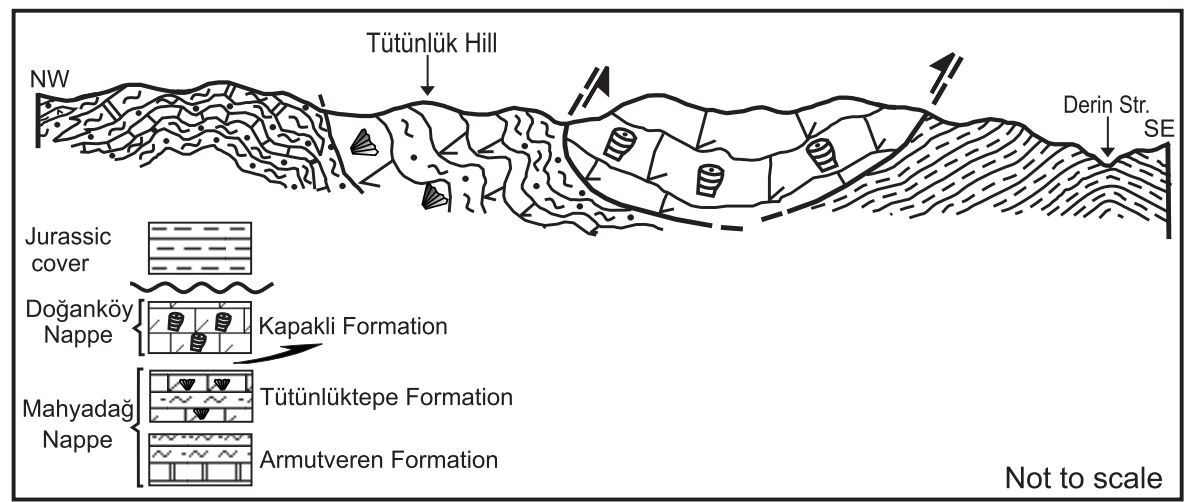

Fig. 3. Geological cross-sections showing the contact relationships between underlying and overlying successions of the Tütünlüktepe Formation

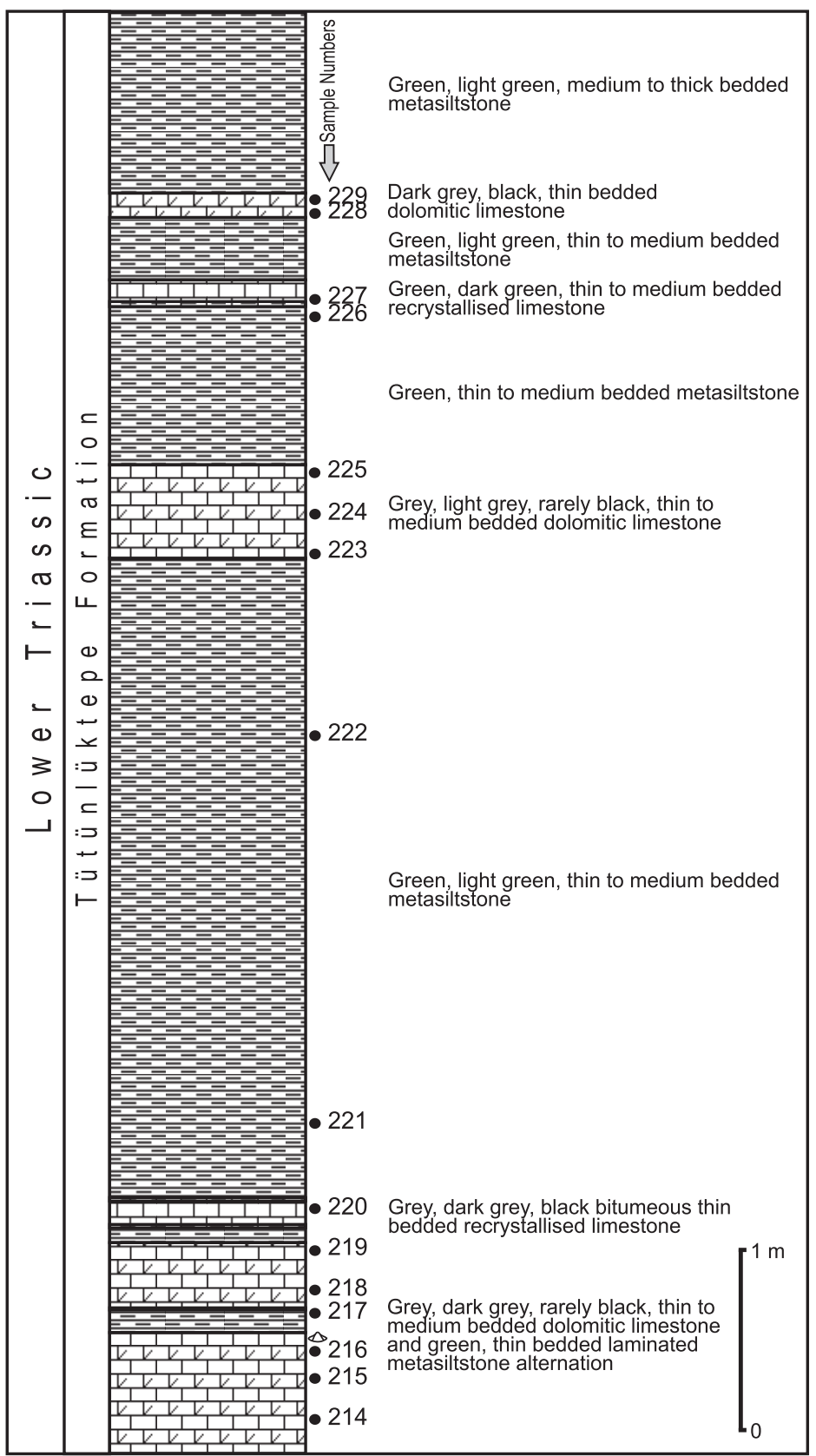

Fig. 4. Stratigraphical section of the Çağlayık section, showing the sampling levels and lithology

\section{INTERPRETATION}

The characteristic foraminiferal assemblage permits an exact chronostratigraphic determination for the recrystallised limestones, dolomitic limestones and metasiltstones of the section (Fig. 6). The foraminiferal assemblage of Çağlayık section from bottom to top (10-KK214-10-KK-229) comprises only a post-extinction population characterized by disaster elements of the Early Triassic Epoch (Induan; Fig. 6).

Another argument supporting the Induan age of the studied rocks is the observation of the "Lilliput effect" (Urbanek, 1993), a pattern of size change through extinction events. Early Triassic animal body fossils and trace fossils are small relative to those in older and younger intervals. Size decreases sharply through the endPermian extinction event and Permian-Triassic boundary and the smallest sizes are encountered in the earliest Induan (Song et al., 2011). According to the study of Twitchett (2007), all animal groups suffered a size reduction after the Late Permian extinction event and the body sizes of these animal groups remained low when compared to those of earlier Permian or later Triassic times. These smallest sizes of organisms are observed in parvus and isarcisa zones of the earliest Induan (Twitchett, 2006).

The lowest Triassic strata from the different Permian-Triassic sections of the world (e.g., Altıner et al., 2005; Groves et al., 2005, 2007; Shen et al., 2006; Haas et al., 2007) are characterized by mainly dolomitic limestone, recrystallised limestone with numerous tiny foraminifers and regular and planar millimetre-scale laminations with abundant pyrite crystals as in the Çağlayık section (Fig. 7). The occurrence of pyrite-rich lithofacies in Permian-Triassic boundary successions is evidence for widespread anoxia in shallow marine environments during the end-Permian mass extinction (Wignall and Hallam 1992, 1993; Wignall and Twitchett, 1996).

\section{DISCUSSION}

In the Çağlayık section, the recovered foraminiferal fauna is mainly represented by specimens of the genera Diplosphaerina, Arenovidalina, Globivalvulina, Earlandia, Hemigordius, Rectostipulina and Postcladella. The determined taxa include common elements of the Late Permian and the Early Triassic. The foraminiferal assemblage of both time intervals broadly indicates the 

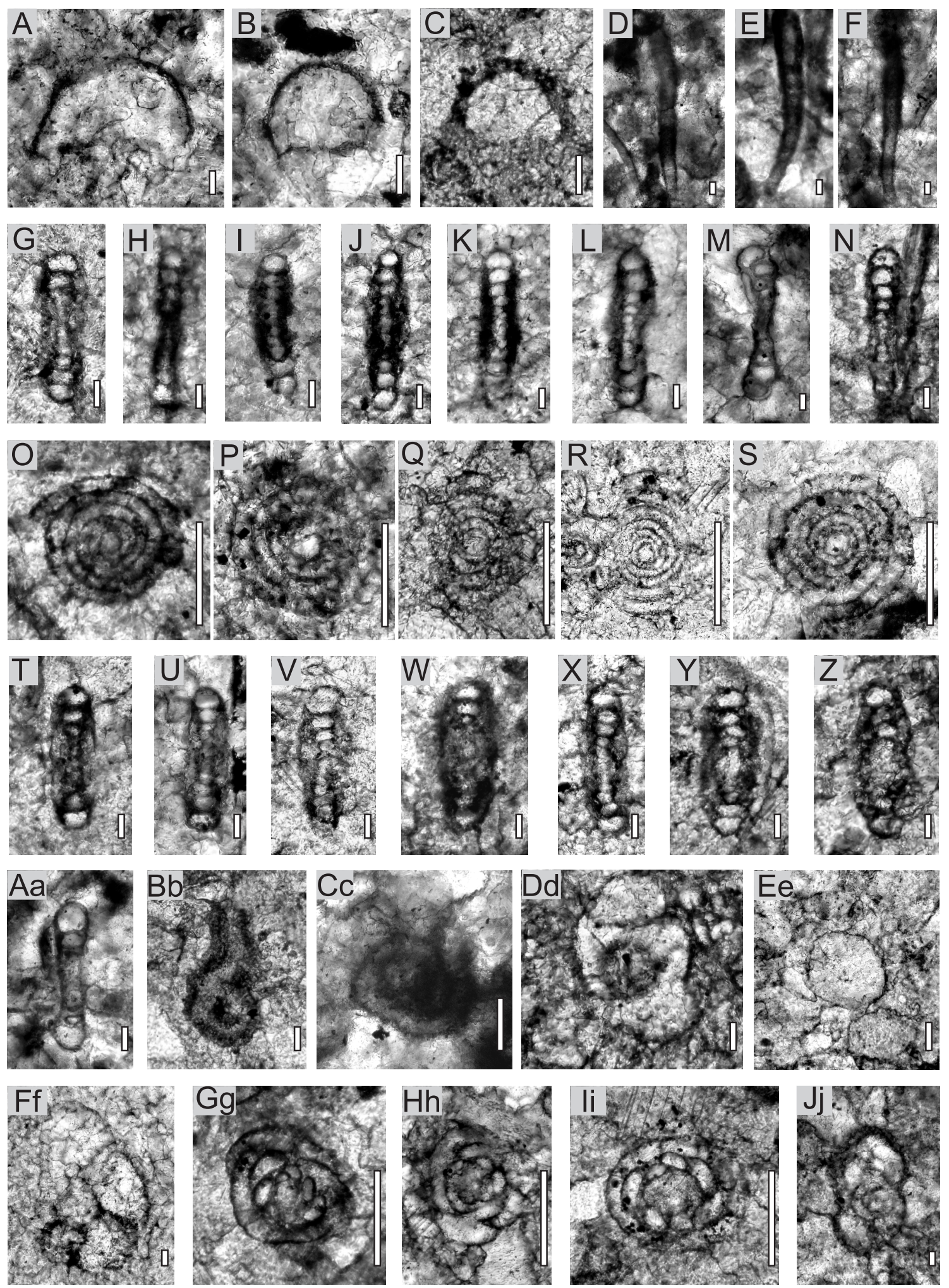

Fig. 5. Foraminifers of the Çağlayık section

A-C - Diplosphaerina inaequalis (Derville) (A, B - 09-KK-216, C - 09-KK-229); D-F - Earlandia sp. (09-KK-216); G-N Hemigordius spp. (G-N-09-KK-216, N-09-KK-220); O-S - Ammodiscus spp. (O - 09-KK-227, P-S - 09-KK-216); T-Z - Arenovidalina chialingchiangensis (Ho) (T-X - 09-KK-216, Y - 09-KK-220, Z - 09-KK-215); Aa-Cc - Postcladella kalhori (Brönniman, Zaninetti and Bozorgnia) (Aa, Cc - 09-KK-216, Bb - 09-KK-220); Dd, Ee - ?Rectostipulina quadrata Jenny-Deshusses (Dd - 09-KK-225, Ee - 09-KK-216); Ff - Globivalvulina bulloides (Brady) (09-KK-216); Gg-li Glomospira sp. (09-KK-220); Jj - Endoteba? sp. (09-KK-228); scale bar is $20 \mu \mathrm{m}$ 
end-Permian mass extinction and its disaster, survivor and aftermath components.

The Permian relict foraminifers consist of Globivalvulina bulloides (Brady), Diplosphaerina inaequalis (Derville), ?Rectostipulina quadrata Jenny-Deshusses and Hemigordius sp. Globivalvulina bulloides (Brady) is very common in Permian strata but also occur in lowermost Triassic successions as a survivor of the Permian-Triassic mass extinction (e.g., Bed 27, Meishan section from the southern China; Song et al., 2009a). These taxa show many similarities to those of the Meishan section "Survival Fauna Beds" (Bed 25-27; Chen et al., 2006) and compare with those of the second episode of extinction (Song et al., 2007). These Permian relict faunas have been described together with the earliest Triassic foraminifers such as Postcladella kalhori (Brönnimann, Zaninetti and Bozorgnia) and Areno-

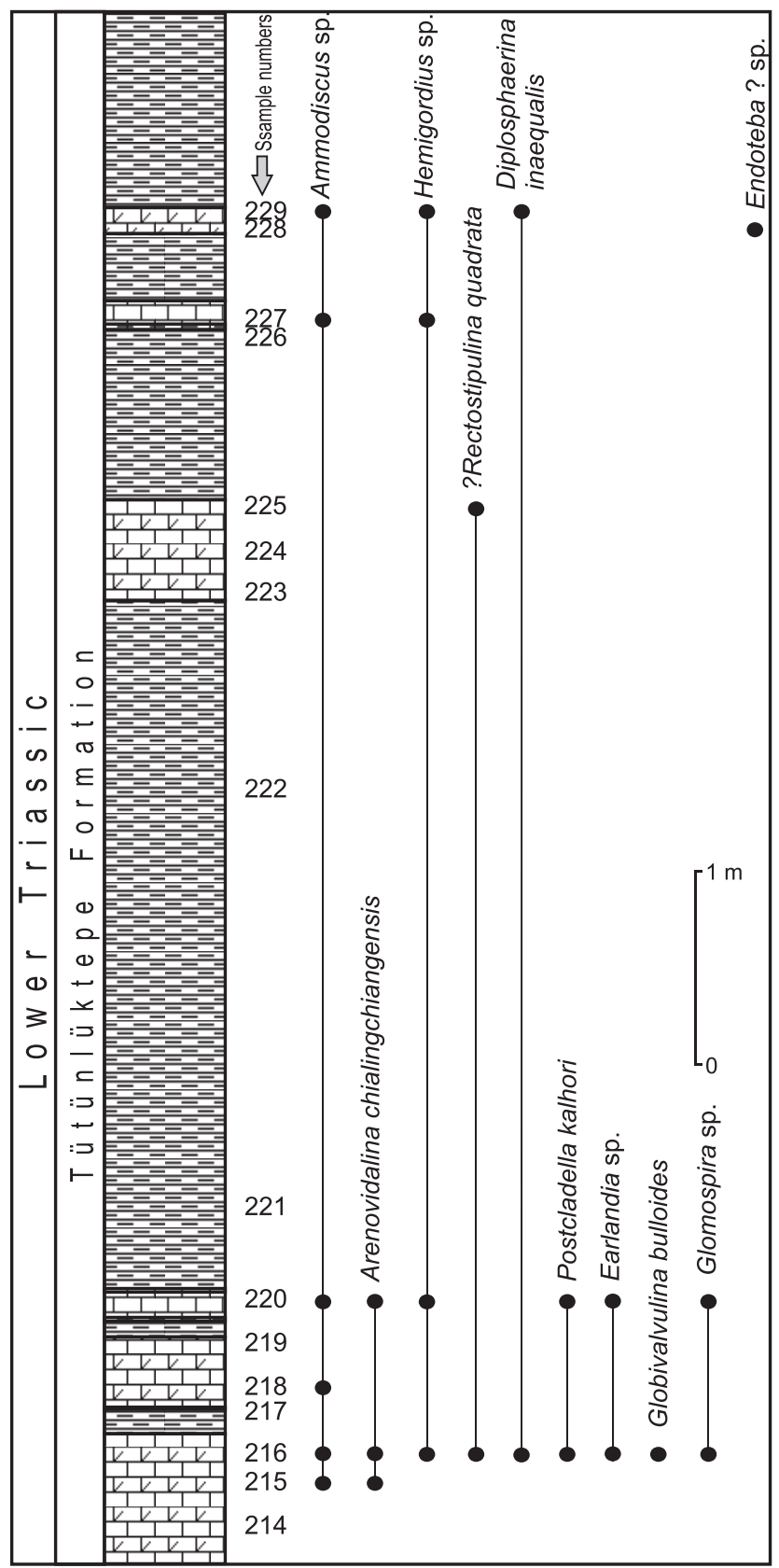

Fig. 6. Stratigraphic occurrences of foraminifers in the Çağlayık section

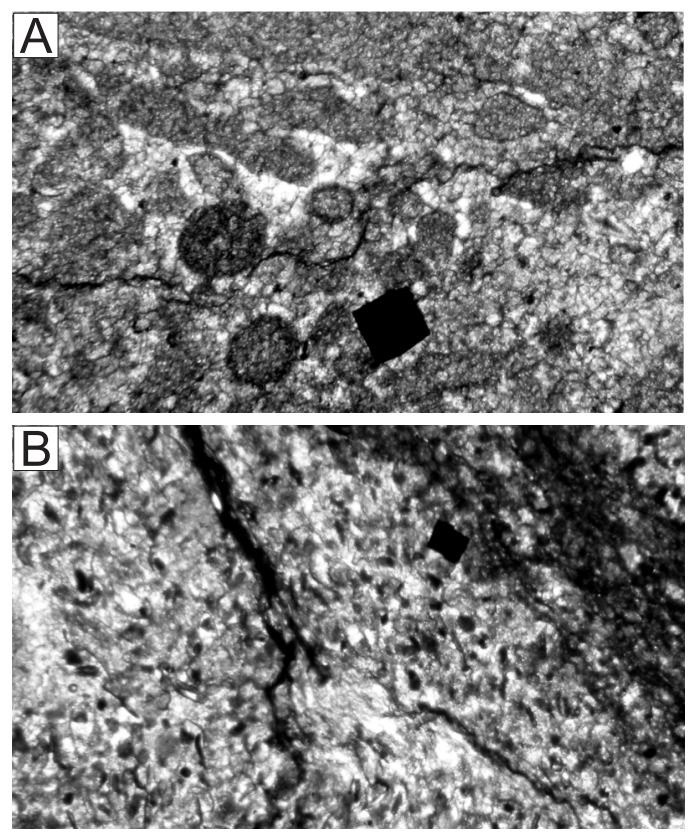

Fig. 7. Occurrences of pyrite cubes in the dolomitic limestone levels

A - sample 09-KK-216; B - sample 09-KK-228

vidalina chialingchiangensis (Ho). Postcladella kalhori (Brönnimann, Zaninetti and Bozorgnia) (with the type species Rectocornuspira kalhori Brönnimann, Zaninetti and Bozorgnia) is well-presented in the studied material. Krainer and Vachard (2011) recognized that Cornuspira? mahajeri and Rectocornuspira kalhori belong to the same genus and introduced the taxon as Postcladella kalhori $\mathrm{n}$. comb. The known stratigraphic distribution of Postcladella kalhori is from latest Middle Permian to earliest Triassic strata; it is especially common and characteristic of Induan (earliest Triassic) strata globally, for instance, in South China (Ezaki et al., 2003; Song et al., 2007, 2009b; Galfetti et al., 2008), southern Turkey (Crasquin-Soleau et al., 2004; Altıner et al., 2005; Groves et al., 2005; Payne et al., 2007) and northern Italy (Groves et al., 2007). Some questionable occurrences of this taxon are indicated in the Olenekian (late Early Triassic; Krainer and Vachard, 2011). Representatives of the genus Earlandia are known from the level above the P-Tr mass extinction horizon in South China (Ezaki et al., 2003; Song et al., 2007, 2009a, b), southern Turkey (Altıner et al., 2005; Groves et al., 2005; Angiolini et al., 2007), Italy (Groves et al., 2007) and Hungary (Hips and Haas, 2006). Postcladella kalhori and Earlandia occur together with inferred disaster taxa foraminifer in the aftermath of the P-Tr crisis (Hallam and Wignall, 1997; Groves and Altıner, 2005; Groves et al., 2005, 2007; Song et al., 2007, 2009a, b).

The genus Arenovidalina is interpreted as a Lazarus taxon by Zaninetti et al. (1992), Rettori (1995), Altıner et al. (2005) and Groves and Altıner (2005) and its occurrence in Early Triassic (Induan?-Olenekian stages) probably represents a phyletic continuation of Permian forms assigned to Neohemigordius (Altıner et al., 2005). Based on published data (Altıner et al., 2005; Groves and Altıner, 2005; Song et al., 2011) the known stratigraphic range of Arenovidalina chialingchiangensis $(\mathrm{Ho})$ is from the Olenekian (Early Triassic) to Anisian (Middle Triassic).

The successions from the Çağlayık section are thin overall because of the limited exposures of the Tütünlüktepe Formation which is 10-m-thick in the Turkish part of the "Strandzha Massif" and has no exposure in the Bulgarian part. The underlying and 
the overlying successions of the Tütünlüktepe Formation and their foraminiferal distribution could not be studied to see the contact with Permian units. We agree with previous studies that treated both Earlandia and Postcladella as disaster taxa (Hallam and Wignall, 1997; Groves and Altıner, 2005; Groves et al., 2005, 2007; Song et al., 2007, 2009a, b) and Diplosphaerina inaequalis (Derville), ?Rectostipulina quadrata Jenny-Deshusses, Arenovidalina and Glomospira sp. as Lazarus taxa (Song et al., 2011). Both disaster and Lazarus taxa described here characterize the post-extinction foraminiferal assemblage.

\section{CONCLUSIONS}

Five species and five species in open nomenclature belonging to ten genera of the calcareous foraminifers were discovered in recrystallised limestones to the south-east of Çağlayık village on the "Strandzha Massif". The foraminifera discovered represent a post-extinction population of Induan stage (Early
Triassic) and comprise disaster and Lazarus taxa. The present study identified for the first time the presence of Permian foraminifers in the "Strandzha Massif" as relict in a post-extinction foraminiferal assemblage. The foraminifer associations are represented by widely distributed species and genera in association with Permian-Triassic boundary sections, allowing good correlation.

Acknowledgements. This study was carried out as part of a joint project ("Tectonostratigraphic Characteristics of the Strandzha Tectonic Belt and Correlation of the Sequences at the Turkish-Bulgarian Border") between the General Directorate of Mineral Research and Exploration (MTA) and the Geological Institute of the Bulgarian Academy of Sciences (BAS). The authors would like to extent their thanks to the both partner's project members for their contributions during the field work. We also thank R. Rettori and H. Song and the journal editor T. Peryt for their constructive and helpful comments that helped to improve the manuscript significantly.

\section{REFERENCES}

Altıner D., Groves J.R., Özkan-Altıner S. (2005) Calcareous foraminiferal recovery from the end-Permian mass extinction, southern Turkey. Albertiana, 33: 14-17.

Angiolini L., Carabelli L., Nicora A., Crasquin-Soleau S., Marcoux J., Rettori R. (2007) Brachiopods and other fossils from the Permo-Triassic boundary beds of the Antalya Nappes (SW Taurus, Turkey). Geobios, 40: 715-729.

Aydın Y. (1974) Etude pétrographique et géochimique de la partie centrale du Massif d'Istranca (Turquie). These l'Universitè de Nancy.

Aydın Y. (1982) Geology of Yıldız Mountains (Strandja) Massif (in Turkish). ITU Fac. of Eng. and Arc. Thesis.

Bambach R.K., Knoll A.H., Sepkoski J.J. Jr. (2002) Anatomical and ecological constraints on Phanerozoic animal diversity in the marine realm. Proceeding of the National Academy of Sciences of the United States of America, 99: 6854-6859.

Baud A., Magaritz M., Holser W.T. (1989) Permian-Triassic of the Tethys: carbon isotope studies. Geologische Rundschau, 78: 649-677.

Becker L., Poreda R.J., Hunt A.G., Bunch T.E., Rampino M. (2001) Impact event at the Permian-Triassic boundary: evidence from extraterrestrial noble gases in fullerenes. Science, 291: $1530-1533$

Bedi Y. (2009) 1/25.000 scale Turkish geological map, Kırklareli D18-c4 Quadrangle (in Turkish). Archive of the Geological Research Department, General Directorate of Mineral Research and Exploration (unpublished).

Bedi Y., Vasilev E., Dabovski C., Ergen A., Okuyucu C., Doğan A., Tekin U. K., Ivanova D., Boncheva I., Lakova I., Sachanski V., Kuscu I., Tuncay E., Demiray D.G., Soycan H., Göncüoğlu M.C. (2013) New age data from the tectonostratigraphic units of the Istranca "Massif" in NW Turkey: a correlation with SE Bulgaria. Geologica Carpathica, 64: 255-277.

Chatalov G.A. (1980) Two facies type of Triassic in Strandza mountain, SE Bulgaria. Rivista Italiana di Paleontologia i Stratigrafia, 85: 1029-1046.

Chatalov G.A. (1985) Stratigraphy of Strandzha-type Triassic (Strandzha Mountain, southest Bulgaria). Geologica Balcanica, 15: 3-38.

Chatalov G.A. (1990) Geology of the Strandja Zone in Bulgaria (in Bulgarian). Publishing House Bulgarian Academy of Sciences.
Chatalov G.A., Trifonova E. (1985) Contribution to the stratigraphy of the Balkanide type Triassic in Sveti Ilija Ridge and Strandzha Mountain (SE Bulgaria). Review of the Bulgarian Geological Society, 156: 312-324.

Chen Z.Q., Kaiho K., George A.D., Tong J. (2006) Survival brachiopod faunas of the end-Permian mass extinction from the southern Alps (Italy) and South China. Geological Magazine, 143: 301-327.

Crasquin-Soleau S., Marcoux J., Angiolini L., Richoz S., Nicora A., Baud A., Bertho Y. (2004) A new ostracode fauna from the Permian-Triassic boundary in Turkey (Taurus, Antalya Nappes). Micropaleontology, 50: 281-295.

Dabovski C., Zagorchev I. (2009) Introduction: Mesozoic evolution and Alpine structure. In: Geology of Bulgaria Volume II, Part. 5. Mesozoic Geology (eds. I. Zagorchev, C. Dabovski, T. Nikolov): 15-37. Prof. Marin Drinov Academic Publishing House, Sofia.

Erwin D.H. (1993) The Great Paleozoic Crisis: Life and Death in the Permian. Columbia University Press, New York.

Erwin D.H. (2006) Extinction: How Life on Earth Nearly Ended 250 Million Years Ago. Princeton University Press Princeton.

Ezaki Y., Liu J., Adachi N. (2003) Earliest Triassic microbialite micro- to megastructures in the Huaying area of Sichuan Province, South China: implications for the nature of oceanic conditions after the end-Permian extinction. Palaios, 18: 388-402.

Galfetti T., Bucher H., Martini R., Hochuli P.A., Weissert H., Crasquin-Soleau S., Brayard A., Goudemand N., Bruhwiler T., Guodun K. (2008) Evolution of Early Triassic outer platform paleoenvironments in the Nanpanjiang Basin (South China) and their significance for the biotic recovery. Sedimentary Geology, 204: $36-60$

Gerdjikov I. (2005a) Thrust tectonics in Strandja Zone: new data the Dervent Heights, SE Bulgaria (in Bulgarian). Annual of the University of Mining and Geology, Geology and Geophysics, 48: $41-46$.

Gerdjikov I. (2005b) Alpine metamorphism and granitoid metamorphism in the Strandja Zone: new data from the Sakar Unit, SE Bulgaria. Turkish Journal of Earth Science, 14: 167-183.

Groves J.R., Altiner D. (2005) Survival and recovery of calcareous foraminifera pursuant to the end-Permian mass extinction. Comptes Rendus Palevol, 4: 487-500.

Groves J.R., Altıner D., Rettori R. (2005) Extinction, survival, and recovery of lagenide foraminifers in the Permian-Triassic bound- 
ary interval, Central Taurides, Turkey. The Paleontological Society Memoir, 62: 1-38.

Groves J.R., Rettori R., Payne J.L., Boyce M.D., Altıner D. (2007) End-Permian mass extinction of Lagenide foraminifers in the Southern Alps (Northern Italy). Journal of Paleontology, 81: 415-434.

Haas J., Demény A., Hips K., Zajzon N., Weiszburg T.G., Sudar M., Pálfy J. (2007) Biotic and environmental changes in the Permian-Triassic boundary interval recorded on a western Tethyan ramp in the Bükk Mountains, Hungary. Global and Planetary Change, 55: 136-154

Hagdorn H., Göncüoğlu M.C. (2007) Early-Middle Triassic echinoderm remains from the Istranca Massif, Turkey. Neues Jahrbuch für Geologie und Paläontologie Abhandlungen, 246: 235-245.

Hallam A., Wignall P.B. (1997) Mass Extinctions and their Aftermath. Oxford University Press, Oxford.

Hallam A., Wignall P.B. (1999) Mass extinctions and sea-level changes. Earth Science Review, 48: 217-250.

Hips K., Haas J. (2006) Calcimicrobial stromatolites at the Permian-Triassic boundary in a western Tethyan section, Bükk Mountains, Hungary. Sedimentary Geology, 185: 239-253.

Jin Y.G., Wang Y., Wang W., Shang Q.H., Cao C.Q., Erwin D.H. (2000) Pattern of marine mass extinction near the Permian-Triassic boundary in South China. Science, 289: 432-436.

Kaiho K., Kajiwara Y., Nakano T., Miura Y., Kawahata H., Tazali K., Ueshima M., Chen Z.Q., Shi G.R. (2001) End Permian catastrophe by a bolide impact: evidence of a gigantic release of sulfur from the mantle. Geology, 29: 815-818.

Knoll A.H., Bambach R.K., Payne J L., Pruss S., Fisher W.W. (2007) Paleophysiology and end-Permian mass extinction. Earth and Planetary Science Letters, 256: 295-313.

Krainer K., Vachard D. (2011) The Lower Triassic Werfen Formation of the Karawanken Mountains (Southern Austria) and its disaster survivor microfossils, with emphasis on Postcladella $\mathrm{n}$. gen. (Foraminifera, Miliolata, Cornuspirida). Revue de Micropaléontologie, 54: 59-85.

Okay A., Yurtsever A. (2006) Metamorphic rock units of Strandja Massif with post metamorphic Cretaceous rock units. Lithostratigraphic units of Thrace region. Committee of Stratigraphy Lithostratigraphic Units, Series 2. General Directorate of Mineral Research and Exploration Publications: 1-41.

Okay A., Satır M., Tüysüz O., Akyüz S., Chen F. (2001) The tectonics of the Strandja Massif: late-Variscan and mid-Mesozoic deformation and metamorphism in the northern Aegean. International Journal of Earth Sciences, 90: 217-233.

Pamir H.N., Baykal F. (1947) Geological structure of Strandja Massif (in Turkish). MTA Report 2257 (unpublished).

Payne J.L., Lehrmann D.J., Follett D., Seibel M., Kump L.R., Riccardi A., Altıner D., Sano H., We J. (2007) Erosional truncation of uppermost Permian shallow-marine carbonates and implications for Permian-Triassic boundary events. GSA Bulletin, 119: 771-784.

Rampino M.R., Adler A.C. (1998) Evidence for abrupt latest Permian mass extinction of foraminifera: results of tests for the Signor-Lipps effect. Geology, 26: 415-418.

Rettori R. (1995) Foraminiferi del Trias inferiore e medio della Tetide: revisione tassonomica, stratigrafia e interpretazione filogenetica. Publications du Département de géologie et de paléontologie de l'Université de Genève, 18.

Shen S.Z., Cao C.Q., Henderson C.M., Wang X.D., Sh G.R., Wang Y., Wang W. (2006) End-Permian mass extinction pattern in the northern peri-Gondwanan region. Palaeoworld, 15: 3-30.

Song H.J., Tong J.N., Zang K.X., Wang Q.X., Chen Z.Q. (2007) Foraminiferal survivors from the Permian-Triassic mass extinction in the Meishan section, South China. Palaeoworld, 16: 105-119.
Song H.J., Tong J.N., Chen Z.Q. (2009a) Two episodes of foraminiferal extinction near the Permian-Triassic boundary at the Meishan section, South China. Australian Journal of Earth Sciences, 56: 765-773.

Song H.J., Tong J.N., Chen Z.Q., Yang H., Wang Y. (2009b) End-Permian mass extinction of foraminifers in the Nanpanjiang Basin, South China. Journal of Paleontology, 83: 718-738.

Song H., Wignall P.B., Chen Z., Tongi J., Bond D.P.G., Lai X., Zhao X., Jiang H., Yan C., Niu Z., Chen J., Yang H., Wang Y. (2011) Recovery tempo and pattern of marine ecosystems after the end-Permian mass extinction. Geology, 39: 739-742.

Song H., Wignall P.B., Tong J., Yin H. (2013) Two pulses of extinction during the Permian-Triassic crisis. Nature Geoscience, $\mathbf{6}$ : 52-56.

Şengör A.M.C., Yılmaz Y., Sungurlu O. (1984) Tectonics Mediterranean Cimmerides: nature and evolution of the western termination of Paleo-Tethys. Geological Society Special Publications, 17: $77-112$.

Trifonova E. (1978) New foraminifera species from the Lower Triassic and Middle Triassic in Bulgaria. Doklady Bolgarskoy Akademii Nauk, 31: 1151-1154.

Trifonova E. (1984) Correlation of Triassic foraminifers from Bulgaria and some localities in Europe, Caucasus, and Turkey. Geologica Balcanica, 13: 3-24.

Trifonova E. (1992) Taxonomy of Bulgarian Triassic foraminifera. I. Families Psammosphaeridae to Nodosinellidae. Geologica Balcanica, 2: 3-46.

Trifonova E. (1993) Taxonomy of Bulgarian Triassic foraminifera. II. Families Endothyriidae to Ophthalmidiidae. Geologica Balcanica, 23: 19-62.

Trifonova E. (1994) Taxonomy of Bulgarian Triassic Foraminifera. III. Families Spiroloculiniidae to Oberhausereliidae. Geologica Balcanica, 24: 21-70

Twitchett R.J. (2006) The Lilliput effect in the aftermath of the end-Permian extinction event. Palaeogeography, Palaeoclimatology, Palaeoecology, 252: 132-144

Urbanek A. (1993) Biotic crises in the history of Upper Silurian graptoloids: a palaeobiological model. Historical Biology, 7: 29-50.

Ünal E., Altıner D., Yılmaz I.Ö., Özkan-Altıner S. (2003) Cyclic sedimentation across the Permian-Triassic boundary (Central Taurides, Turkey). Rivista Italiana di Paleontologia e Stratigrafia, 109: 359-376.

Üşümezsoy Ş. (1982) Petrogenetic evolution of Strandja Massif (in Turkish). Istanbul University Faculty of Geosciences. Ph. D. Thesis.

Weidlich O., Kiessling W., Flügel E. (2003) Permian-Triassic boundary interval as a model for forcing marine ecosystem collapse by long-term atmospheric oxygen drop. Geology, 31: 961-964.

Wignall P.B., Hallam A. (1992) Anoxia as a cause of the Permian/Triassic mass extinction: facies evidence from northern Italy and the western United States. Palaeogeography, Palaeoclimatology, Palaeoecology, 93: 21-46.

Wignall P.B., Hallam A. (1993) Griesbachian (Earliest Triassic) paleoenvironmental changes in the Salt Range, Pakistan and southeast China and their bearing on the Permo-Triassic mass extinction. Palaeogeography, Palaeoclimatology, Palaeoecology, 102: 215-37.

Wignall P.B., Twitchett R.J. (1996) Oceanic anoxia and the endPermian mass extinction. Science, 272: 1155-1158.

Zaninetti L., Martini R., Dumont T. (1992) Triassic foraminifera from Sites 761 and 764, Wombat Plateau, northwestern Australia. Proceedings of the Ocean Drilling Program, Scientific Results, 122: 427-436. 